\title{
Critical Analysis on the Causes of Small Scale Business Failure in Abia State and its Prospects (A Case Study of Ugwunagbo Local Government Area, Abia State)
}

\author{
Dr. Onyebu Chinwe Monica \\ Department of Entrepreneurial Studies, Michael Okpara University of Agriculture, Umudike
}

\begin{abstract}
This research work examines the causes of small scale business failure in Abia state. Survey experimental design is employed in this research work. In conducting the research, questionnaires were used. The sample size for the research consists of three (3) villages in Ugwunagbo Local Government Area. The data collected were tested statistically by the use of mean and simple percentage. The study revealed that lack of enough capital and insufficient income are the major factors that affect the small scale businesses at the Ugwunagbo local government area of Abia State and the solution to this is financial support from government/banks and siting a good location for business and the test of hypothesis revealed that the listed factors has significant effect on the failure of the small scale business at the Ugwunagbo local government area. The following recommendations such as; encouragement of financial institutions to extend loans at a less rate to small-scale business, sourcing of cheap and available raw material locally, consistency in government as it affects small-scale business, enhancement of the managerial skills of managers of small scale business, through seminars and workshops; small scale business owners should engage in business that are less competitive, were suggested.
\end{abstract}

Keywords: Critical analysis, business failure, small scale,

\section{Background of Study}

\section{Introduction}

A small scale business can generally be referred to as a firm that is independently owned and operated and which is not dominant in its field of operation Olokoyo(1998). Although small scale business have great role to play in the developmental process of an economy, they are set to be among the drivers of the economy since most practitioners of suchbusinesses come from that sector of the economy.

Finance has been identified in various business surveys as one of the most important factor that determine the survival and growth of small and medium scale enterprises [SMEs] in both developing and developed countries UNCTAD (2001).

Despite their size, they contribute as low as one percent to Gross Domestic Products (GDP) to the country in contrast to countries like Indonesia, Thailand and India Where they contribute almost $40 \%$ (Sandaet $a l$, 2006). The low contribution in the country is linked to various factors such as lack of managerial capability, poor governance practice, poor managerial talent, legal and regulation weaknesses and financial constraints among others Oguntoye(1997).

In Abia state, there is thousands of business which fall into the category of small scale business. They include weaving, carpentry, pottery and ceramics, farming, retail-trade, tailoring and dress-making. Setting up and managing it, to fruition, can be rewarding, both financially and psychologically. However small-scale business in Nigeria today faces a lot of problems. Many of those business have been forced to wind up due to the economic condition, others management to succeed. The research has also increased the fall of some SmallScale business which has initially commenced with high hopes

It is at this background that the study sets out to look at the various cause of the alarming rate of small scale business failure. The recommendation and conclusion, to be made at the end of this work, will provide enough information to entrepreneur, both potential and existing business managers, to manage their business venture successfully.

\section{Objectives Of The Study}

The main purpose of this study is to identify the Cause of failure of small scale business in Abia state and its prospects. In view of the above, the research tends to find out the following:

a) To expose the various factors, that contributes to the failure of small-scale business.

b) To determine the extent these factors affect the small-scale business.

c) To provides possible ways the small scale business solve the problems. 


\section{Research Questions}

The study will examine the following questions:

a. What are the various factors that contribute to the failure of small scale business at the Ugwunagbo local government area?

b. To what extent does the factors affect the small scale businesses at the Ugwunagbo local government area?

c. What are the possible ways the small scale businesses solve the problems?

\section{Hypothesis}

$\mathrm{H}_{1}$ : Does the factors has any significant effect on the failure of the small scale business at the Ugwunagbo local government area?

\section{Research Design}

\section{Research Methodology}

The study is a descriptive research survey. A sample is selected from the studypopulation, in order to generate the information needed in the subject matter.

\section{Description of Study of Population and Sample Size}

Since the study was based on the causes of small scale business failure in Abia State, it concentrates mostly in Ugwunagbo Local Government Area. It is usually not possible to study the entire large populations of business in Ugwunagbo Local Government Area Abia state, so the research sampled some of the villages in the local government area which are: Umuogele village (40), Umunkama village (40), Mkpumkpuevula village (40) which gave a total of 120 sample size.

\section{Data Collection and Instrument}

In collecting the data and answering research questions, the researcher administered questionnaires to the 120 small-scale businessmen and businesswomen in the selected villages.

\section{Procedures for Data Collection}

To collect reliable information that is been needed, questionnaires were distributed in selected areas. The success in the number of questionnaires was ensured through the deployment of assistance from friends, who reside in those areas. The questionnaire used for this research work is a combination of open ended and close ended questionnaires, where the respondent can give their opinions and tick their choice of answer in the box provided. This form of research has been chosen in order to ease the work of the research in classifying and analyzing individual opinion.

\section{Results And Discussion}

\section{Research questions one}

What are the various factors that contribute to the failure of small scale business at the Ugwunagbo local government area?

Table 1: The factors that contribute to the failure of small scale business

\begin{tabular}{|l|l|l|}
\hline Factors & Frequency & Percentage (\%) \\
\hline Lack of enough capital & 50 & 41.67 \\
\hline Bad location & 15 & 12.50 \\
\hline Insufficient income & 40 & 33.33 \\
\hline Little or no patronage & 6 & 5.00 \\
\hline Family disagreement & 1 & 0.83 \\
\hline Lack of labour & 3 & 2.50 \\
\hline Price of goods & 5 & 4.17 \\
\hline Total & $\mathbf{1 2 0}$ & $\mathbf{1 0 0 . 0}$ \\
\hline
\end{tabular}

Table 1 above showed the factors that contribute to the failure of small scale business at the Ugwunagbo local government area. The result showed that $50(41.67 \%)$ respondents agreed that lack of enough capital contribute to the failure of small scale business, followed by $40(33.33 \%)$ of the respondent for insufficient income and the least factor is family disagreement with $1(2.50 \%)$ of the respondents.

This indicated that lack of enough capital and insufficient income are the major factors that contribute to the failure of small scale business at the Ugwunagbo local government area.

\section{Research questions two}

To what extent does the factors affect the small scale businesses at the Ugwunagbo local government area? 
Table 2: The extent the factors affected the small scale business

\begin{tabular}{|l|l|l|l|l|l|}
\hline Factors & $\begin{array}{l}\text { Very high } \\
\text { extent }(\boldsymbol{\%})\end{array}$ & $\begin{array}{l}\text { High extent } \\
(\boldsymbol{\%})\end{array}$ & $\begin{array}{l}\text { Undecided } \\
(\boldsymbol{\%})\end{array}$ & $\begin{array}{l}\text { Low extent } \\
(\boldsymbol{\%})\end{array}$ & $\begin{array}{l}\text { Very } \\
\text { extent }(\boldsymbol{\%})\end{array}$ \\
\hline Lack of enough capital & $84(70.00)$ & $25(20.83)$ & $1(0.83)$ & $8(6.67)$ & $2(1.67)$ \\
\hline Bad location & $50(41.67)$ & $44(36.67)$ & $0(0.00)$ & $19(15.83)$ & $7(5.83)$ \\
\hline Insufficient income & $89(74.17)$ & $20(16.67)$ & $1(0.83)$ & $6(5.00)$ & $4(3.33)$ \\
\hline Little or no patronage & $40(33.33)$ & $49(40.83)$ & $2(1.67)$ & $18(15.00)$ & $11(9.17)$ \\
\hline Family disagreement & $20(16.67)$ & $60(50.00)$ & $3(2.50)$ & $24(20.00)$ & $13(10.83)$ \\
\hline Lack of labour & $58(48.33)$ & $36(30.00)$ & $1(0.83)$ & $17(14.17)$ & $8(6.67)$ \\
\hline Price of goods & $67(55.83)$ & $38(31.67)$ & $3(2.50)$ & $7(5.83)$ & $5(4.17)$ \\
\hline Mean Total & $58.29(48.57)$ & $38.86(32.38)$ & $1.57(1.31)$ & $14.14(11.79)$ & $7.14(5.95)$ \\
\hline
\end{tabular}

The analysis of the table above revealed the extent the factors listed in table 1 affected the small scale business. $58.29(48.57 \%)$ of the respondents agreed that the listed factors affect small scale business at very high extent, $38.86(32.38 \%)$ of the respondents agreed that the listed factors affect small scale business at high extent, while $14.14(11.79 \%$ ) of the respondents disagreed at low extent and 7.14(5.95\%) of the respondents disagreed at very low extent. The remaining $1.57(1.31 \%)$ of the respondents and being the number of those who chose "undecided" that the effect is interminable. This indicated that most of the respondents agreed that the listed factors affect the small scale business in the Ugwunagbo local government area.

\section{Research question three}

What are the possible ways the small scale businesses solve their problems?

Table 3: The possible ways the small scale businesses solve their problems

\begin{tabular}{|l|l|l|}
\hline Solution & Frequency & Percentage (\%) \\
\hline Financial support from the government/banks & 39 & 32.50 \\
\hline Siting good location & 25 & 20.83 \\
\hline Lending from friend and relatives & 20 & 16.67 \\
\hline Advertisement & 13 & 10.83 \\
\hline Family support & 7 & 5.83 \\
\hline Labour support/assistance & 9 & 7.50 \\
\hline Discount & 7 & 5.83 \\
\hline Total & 120 & 100.0 \\
\hline
\end{tabular}

The analysis of the table above revealed the possible ways the small scale businesses solve their problems. $39(32.50 \%)$ of the respondents agreed that the financial support from the government/banks serves as the major possible way the small scale businesses solves their problems, followed by $25(20.83 \%)$ of the respondents who agreed that siting good location also solves the small scale business's problems. The least response goes to solution from the family support and discounting with the same $7(5.83 \%)$ number of respondents. This indicated that financial support from the government/banks serves as the best ways small scale businesses can solve their problems at the Ugwunagbo local government area.

Test of Hypothesis

Does the factors has any significant effect on the failure of the small scale business at the Ugwunagbo local government area?

Table 4: Effect of the listed factors on the failure of the small scale business

\begin{tabular}{|l|l|l|l|}
\hline Option & No of Responses & Percentage (\%) & Decision \\
\hline Lack of enough capital & 64 & 3.75 & Agreed \\
\hline Bad location & 67 & 3.97 & Agreed \\
\hline Insufficient income & 78 & 4.54 & Agreed \\
\hline Little or no patronage & 76 & 4.42 & Agreed \\
\hline Family disagreement & 63 & 3.66 & Agreed \\
\hline Lack of labour & 83 & 4.76 & Agreed \\
\hline Price of goods & 69 & 3.96 & Agreed \\
\hline Total & 500 & 29.06 & \\
\hline & & 4.151 & \\
\hline
\end{tabular}

Source: Field Survey, 2016

The table 4 above showed that the respondents agreed that lack of enough capital, bad location, insufficient income, little or no patronage, family disagreement, lack of labour and price of goods serves as the significant factors that causes that failure of the small scale business at the Ugwunagbo local government area with $3.75,3.97,4.54,4.42,3.66,4.76$ and 3.96 means respectively. This indicated that the respondents perceived the options as positive rather than negative considering the clustered mean of 4.151 (from the decision rule any mean response of 3.0 and above should be regarded as a positive influence). 


\section{Conclusion}

This study to a large extent attempted to reveal the causes of small scale business failure and the possible solutions. It also evaluated the possible ways these factors can be solved.

Due to the various contributions of small-scale business in the development ofUgwunagbo local government area of Abia State, both governmental and non-governmental organizations should play their roles; to enhance and encourage more entrepreneurs and small scale business owners in creating employment and reducing or alleviating poverty.

The study revealed that lack of enough capital and insufficient income are the major factors that affect the small scale businesses at the Ugwunagbo local government area of Abia State and the solution to this is financial support from government/banks and siting a good location for business.

\section{Recommendations}

In order to ensure effectiveness in operation of small scale enterprises in Umwunagbo Local Government Area, Abia State, the government should render financial and managerial assistance to small scale businesses in Abia State. Encouragement of financial institutions to extend loans at a less rate to small-scale business, sourcing of cheap and available raw material locally, consistency in government as it affects smallscale business, enhancement of the managerial skills of managers of small scale business, through seminars and workshops; Small scale business owners should engage in business that are less competitive, were suggested. Also small scale business owners should establish in tangible assets that are of long-term in order to help stabilize the economy.

\section{References}

[1]. Olokoyo.S, (1998). Managing your Small-Scale Enterprises successfully: A Guide to Entrepreneurs, managers and Students, Ola Jamon Printers \& Publishers, Kaduna,, Nigeria.

[2]. Oguntoye. A. A. (1997). Report on Financing Small Scale Industries in Nigerian, Economic and Financial review, Central Bank of Nigeria, 28(1):10-13.

[3]. Sanda, A.U., Mikailu, A.S. and Garba,T. (2006). Corporate governance mechanisms and firms' financial performance in Nigeria. Afro-Asian Journal of Finance and Accounting, 2(1): 22-39.

[4]. United Nations Conference on Trade and Development. Geneva. UNCTAD ANNUAL REPORT 2001. 